\title{
Evidence-based management of postoperative nausea and vomiting: a review
}

\author{
[Le traitement des nausées et des vomissements postopératoires fondé sur des
}

données probantes: une revue]

Ashraf S. Habib MBBCH MSc FRCA, Tong J. Gan MB FRCA

Purpose: To provide evidence-based guidelines for the prophylaxis and treatment of postoperative nausea and vomiting (PONV).

Source: Literature from randomized controlled trials, systematic reviews, logistic regression analyses and expert opinion in the management of PONV.

Principal findings: The etiology of PONV is multifactorial. Patient, anesthesia, and surgery related risk factors have been identified. Universal PONV prophylaxis is not cost-effective. Identification of patients at high-risk of PONV allows targeting prophylaxis to those who will benefit most from it. No prophylaxis is needed for patients at low risk for PONV. For patients at moderate risk for PONV, prophylaxis using a single antiemetic or a combination of two agents should be considered. Double and triple antiemetic combinations should be considered for patients at high risk for PONV. Furthermore, a multimodal approach should be adopted incorporating steps to keep the baseline risk of PONV low. The optimum cost-effective approach to the management of PONV will differ between an ambulatory centre and an inpatient hospital setting. For the treatment of established PONV in patients who failed prophylaxis, patients should not receive a repeat dose of the prophylactic antiemetic. Rather, a drug acting at a different receptor should be used. Beyond six hours after surgery, patients can be treated with any of the agents used for prophylaxis, except dexamethasone and transdermal scopolamine.

Conclusion: PONV are common after anesthesia and surgery. We provided evidence-based guidelines for the management of this problem based on the available literature.
Objectif : Énoncer des lignes de conduite fondées sur des données probantes pour la prévention et le traitement des nausées et des vomissements postopératoires (NVPO).

Source : Les publications d'essais contrôlés et randomisés, les études méthodiques, les analyses de régression logistique et l'opinion d'experts sur le traitement des NVPO.

Constatations principales : L'origine des NVPO est multifactorielle. Les facteurs de risque reliés au patient, à l'anesthésie et au type de chirurgie sont connus. La prévention universelle des NVPO n'est pas rentable. L'identification des patients à haut risque de NVPO permet une prévention mieux ciblée. Aucune prophylaxie n'est nécessaire en cas de risque faible. En cas de risque modéré, l'usage d'un seul antiémétique ou d'une combinaison de deux médicaments est une mesure préventive à envisager. On peut combiner deux ou trois antiémétiques en cas de risque élevé. De plus, une approche multimodale doit être adoptée et utilisée par étapes afin de conserver le risque de base faible. La méthode de traitement des NVPO la plus rentable sera différente selon qu'il s'agit d'un patient ambulatoire ou hospitalisé. Le traitement des NVPO établis chez des patients qui n'ont pas répondu au traitement préventif ne doit pas comporter une seconde dose de l'antiémétique prophylactique. Un médicament actif au niveau d'un autre récepteur sera privilégié. Au delà de six heures après l'opération, on peut traiter avec n'importe quel médicament utilisé comme prévention, sauf la dexaméthasone et la scopolamine transdermique.

Conclusion : Les NVPO sont fréquents après l'anesthésie et la chirurgie. Nous avons présenté des lignes de conduite à adopter fondées sur les données probantes de la documentation disponible.

From the Department of Anesthesiology, Duke University Medical Center, Durham, North Carolina, USA.

Address correspondence to: Dr. Tong J. Gan, Department of Anesthesiology, Duke University Medical Center, Durham, NC, 27710, USA. Phone: 919-681-4660; Fax: 919-681-7901; E-mail: gan00001@mc.duke.edu

Disclosures: The following author has conflicts of interest or potential conflicts of interest. T.J. Gan - speaker's bureau: Pharmacia, Abbott, GlaxoSmithKline, Aspect, and Roche; consultant: Pharmacia, Abbott, Roche, and GlaxoSmithKline.

Accepted for publication September 15, 2003.

Revision accepted January 13, 2004. 


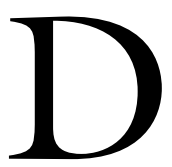

ESPITE significant advances in the area of postoperative nausea and vomiting (PONV) and the introduction of new antiemetic agents, the overall incidence of PONV is currently estimated to be around 20 to $30 \%{ }^{1}$ In certain high-risk patients, this incidence is still as high as $70 \% .^{2}$ PONV can cause prolonged postanesthesia care unit (PACU) stay and unanticipated admissions following ambulatory surgery, therefore increasing medical costs. ${ }^{3}$

Nausea and vomiting are also among the most unpleasant experiences associated with surgery and one of the most common reasons for poor patient satisfaction rating in the postoperative period. ${ }^{4}$ Macario et al. quantified patients' preferences for postoperative outcomes. PONV were among the ten most undesirable outcomes following surgery. Indeed, patients allocated the highest amount (about \$30) to avoid PONV out of a total of $\$ 100$ they were allowed to spend to avoid all complications. ${ }^{5}$ Gan and colleagues also reported that surgical patients were willing to pay up to US $\$ 100$, at their own expense, to avoid PONV. ${ }^{6}$

In this article, we will present evidence regarding the prophylaxis and treatment of PONV based on the available literature using data from randomized controlled trials, systematic reviews, logistic regression analyses, and expert opinion. We will adopt the rating scale used by a consensus panel of experts who generated guidelines for the management of PONV (Table I). ${ }^{7}$ The cost-effectiveness of antiemetics and post-discharge nausea and vomiting will also be discussed.

\section{Risk stratification}

Universal PONV prophylaxis is not cost-effective and puts patients at unnecessary risk of drug related adverse effects. Identification of patients at high risk for PONV allows targeting prophylaxis to those who will benefit most from it. Patient, anesthesia, and surgery related risk factors have been identified ${ }^{8-18}$ (Table II). There is controversy regarding a number of previously reported risk factors. For instance, while certain types of surgery were reported to be associated with an increased risk for PONV, ${ }^{15}$ Apfel and colleagues did not find the type of surgery to be an independent risk factor for PONV. They suggested that the high incidence of PONV after certain operations might be caused by the involvement of high risk patients. ${ }^{2}$ Similarly, the results of studies investigating the relationship of PONV to the stage of the menstrual cycle were inconsistent. While some studies reported an increased susceptibility to PONV during the first seven days of the menstrual cycle, ${ }^{19,20}$ this was not confirmed in other studies. ${ }^{21}$ Recently, a systemat-
TABLE I Evidence rating scales ${ }^{7}$

Level of evidence based on study design

I Large randomized, controlled trial, $n \geq 100$ per group

II Systematic review

III Small randomized, controlled trial, $n<100$ per group

IV Non-randomized, controlled trial or case report

$\mathrm{V}$ Expert opinion

Strength of conclusion or recommendation

A Good evidence to support the conclusion or recommendation

B Fair evidence to support the conclusion or recommendation

C Insufficient evidence to recommend for or against

ic review of the results of all available studies suggested that the phase of the menstrual cycle had no impact on the occurrence of PONV (IIA). ${ }^{22}$ Another recent systematic review also reported that an increased body mass index is not a risk factor for PONV (IIA). ${ }^{23} \mathrm{~A}$ recent study suggested that differences exist in risk factors of postoperative nausea $v s$ vomiting. The authors reported that female gender, non-smoking status, and general anesthesia increase both PONV; whereas a history of migraine and the type of surgery tend to influence nausea only. ${ }^{24}$

In the pediatric population, only vomiting is reported due to difficulties in eliciting nausea in the young age group. Postoperative vomiting occurs in 13 to $42 \%$ of all pediatric surgical patients. ${ }^{25} \mathrm{~A}$ peak incidence of 34 to $51 \%$ occurs in the six to $16 \mathrm{yr}$ age group. ${ }^{26}$ Prior to puberty, gender differences for postoperative vomiting have not been identified. ${ }^{7}$ Operations associated with a high incidence of postoperative vomiting in children include strabismus, adenotonsillectomy, hernia repair, orchidopexy and penile surgery. ${ }^{27}$

A number of PONV risk scoring systems have been developed. In 1993, Palazzo and Evans prospectively studied 147 patients undergoing minor orthopedic surgery. Using logistic regression analysis, they concluded that the probability of postoperative sickness in the first $24 \mathrm{hr}$ after surgery can be estimated using the following equation: logit postoperative sickness $=-5.03$ +2.24 (postoperative opioids) +3.97 (previous sickness history $)+2.4$ (gender $)+0.78$ (history of motion sickness) -3.2 (gender $\times$ previous sickness history). ${ }^{28}$

Subsequently, Koivuranta studied 1,107 in-patients and used a logistic regression model to generate a score based on the strongest five predictors for PONV: score $=0.93$ (if female $)+0.82$ (if previous PONV) +0.75 (if duration of surgery over $60 \mathrm{~min}$ ) + 0.61 (if nonsmoker) +0.59 (if history of motion sickness). ${ }^{16}$

More recently, in a study of 2,722 patients, Apfel et al. developed a simplified risk score consisting of four predictors: female gender, history of motion sickness 
TABLE II Risk factors for postoperative nausea and vomiting (PONV)

\begin{tabular}{|c|c|c|}
\hline Anesthetic factors & Patient factors & Surgical factors \\
\hline 1. Volatile agents (IIA) ${ }^{8}$ & 1. Female gender $(\mathrm{IA})^{2,15}$ & $\begin{array}{l}\text { 1. Long surgical procedures (each } 30 \\
\text { min increase in duration increases } \\
\text { PONV risk by } 60 \%)(\text { IVA })^{15}\end{array}$ \\
\hline 2. Nitrous oxide (IIA) ${ }^{9}$ & 2. History of PONV or motion sickness (IVA) $)^{2,15,16}$ & $\begin{array}{l}\text { 2. Certain types of surgery e.g., intra- } \\
\text { abdominal, major gynecological, } \\
\text { laparoscopic, breast, ENT, strabismus } \\
\text { (IVB })^{15,17,18}\end{array}$ \\
\hline $\begin{array}{l}\text { 3. Opioids, intraoperative (IIA) and } \\
\text { postoperative (IVA) })^{2,10-13} \\
\text { 4. High doses of neostigmine (IIA) })^{14}\end{array}$ & 3. Non-smoking status (IVA) $)^{2,16}$ & \\
\hline
\end{tabular}

TABLE III Options available for the management of postoperative nausea and vomiting (PONV)

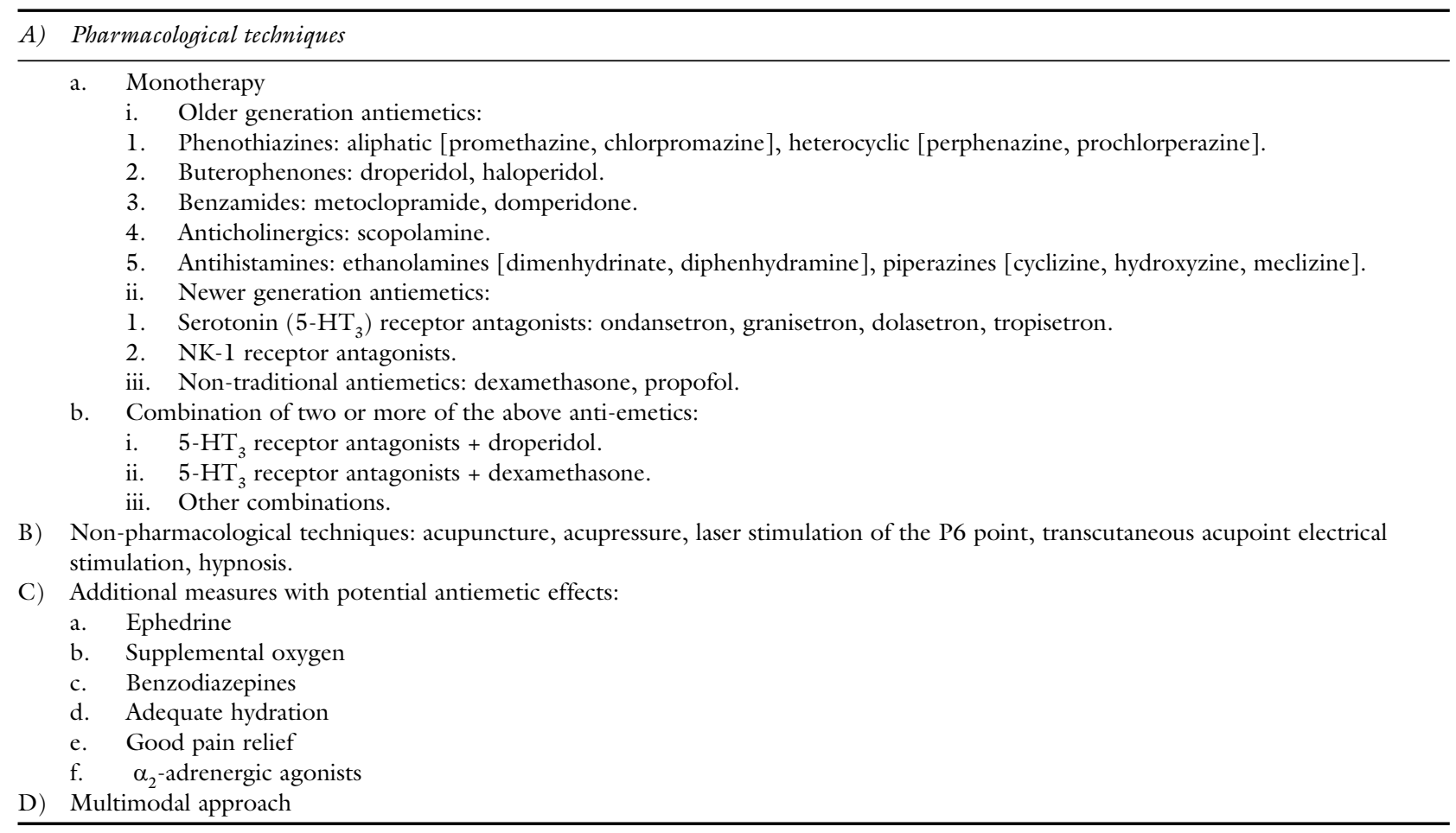

or PONV, non-smoking status and the use of opioids for postoperative analgesia. If none, one, two, three or four of these risk factors were present, the incidences of PONV were 10, 21, 39, 61 and 79\% respectively. ${ }^{2}$

\section{Currently available antiemetics}

There are at least four major receptor systems involved in the etiology of PONV. Currently available antiemetics may act at the cholinergic (muscarinic), dopaminergic (D2), histaminergic $(\mathrm{Hl})$ or serotonergic $\left(5-\mathrm{HT}_{3}\right)$ receptors. NK-1 receptor antagonists are also being investigated. The available options for PONV prophylaxis are presented in Table III.
A number of antiemetic interventions have been studied in systematic reviews. ${ }^{9,14,29-38}$ As a measure of antiemetic efficacy, the number needed-to-treat (NNT) is calculated. In this context, the NNT indicates the number of patients needed to receive a particular antiemetic intervention to prevent one emetic event that would have occurred had the patient not received the intervention. The NNT of different antiemetic therapies that have been studied in systematic reviews are presented in Table IV (available as additional material at www.cja-jca.org). Early events (nausea or vomiting) refer to PONV within zero to six hours postoperatively. Late PONV refers to events 
between zero to $24 \mathrm{hr}$ or zero to $48 \mathrm{hr}$. As a measure of side effects, the number needed-to-harm $(\mathrm{NNH})$ is calculated. The $\mathrm{NNH}$ refers to the number of patients needed to be treated with an intervention for one to show an adverse reaction, who would not have shown this reaction had they not received the intervention. The NNH of antiemetic agents reported in metaanalyses are summarized in Table $\mathrm{V}$ (available as Additional Material at www.cja-jca.org).

\section{Serotonin receptor antagonists}

The $5-\mathrm{HT}_{3}$ receptor antagonists are highly specific and selective for nausea and vomiting. Members of this group exert their effects by binding to the $5-\mathrm{HT}_{3}$ receptor in the chemoreceptor trigger zone and at vagal afferents in the gastrointestinal tract. Their favourable side effects profile, and in particular the lack of sedation, makes them particularly suitable for ambulatory surgery.

Ondansetron was the first member of this group to be marketed in the USA and was the most widely studied. The anti-vomiting efficacy of ondansetron is better than its anti-nausea efficacy (IIA)..$^{33}$ It is most effective when given at the end of surgery (IIIA). ${ }^{39,40}$ The recommended dose for prophylaxis is 4 to $8 \mathrm{mg}$ iv in adults (IIA) and 50 to $100 \mu \mathrm{g} \cdot \mathrm{kg}^{-1}$ in children (IIA). ${ }^{33}$ The NNT to prevent PONV was between 5 and 6 . The reported side effects include headache $(\mathrm{NNH}=36)$, dizziness, flushing, elevated liver enzymes $(\mathrm{NNH}=31)$ and constipation $(\mathrm{NNH}=23){ }^{41}$

Dolasetron is structurally related to tropisetron and granisetron. The recommended $i v$ dose for prophylaxis and treatment of PONV is $12.5 \mathrm{mg}$ (IA). ${ }^{42}$ The timing of administration of dolasetron appears to have little effect on its efficacy when administered for the prophylaxis of PONV (IIIA). ${ }^{43}$

Tropisetron has been studied in Europe and showed efficacy in the management of PONV. The recommended prophylactic dose is 2 to $5 \mathrm{mg}$ (IIA). ${ }^{34}$ The NNT $[95 \%$ confidence interval $(\mathrm{CI})]$ for the prevention of nausea and vomiting at $24 \mathrm{hr}$ postoperatively was 6.7 $(4.8-11.1)$ and $5(3.6-8.3)$ respectively. ${ }^{34}$

Granisetron has also been used in the management of PONV in a dose of $0.35 \mathrm{mg}$ to $3 \mathrm{mg}$ (IA). ${ }^{44,45}$ Although most studies have demonstrated efficacy at $\mathrm{l} \mathrm{mg}$ for prophylaxis, a recent study suggested it might be efficacious at lower doses. ${ }^{46}$ For the treatment of established PONV, a dose of $0.1 \mathrm{mg}$ was found to be efficacious (IA) ${ }^{47}$

Ramosetron is another $5-\mathrm{HT}_{3}$ receptor antagonist with general properties similar to those of ondansetron. It is used in the management of nausea and vomiting induced by cancer chemotherapy. It has also been shown to be effective for PONV prophylaxis in a dose of $0.3 \mathrm{mg}$ given at the end of surgery (IIIA). ${ }^{48}$

COMPARISON BETWEEN THE DIFFERENT 5- HT $_{3}$ RECEPTOR ANTAGONISTS

There is no evidence that there is any difference in efficacy or side-effect profile between the various 5$\mathrm{HT}_{3}$ receptor antagonists, when appropriate doses are used for the management of PONV. In patients undergoing laparoscopic cholecystectomy, there was no difference in antiemetic efficacy between ondansetron $4 \mathrm{mg}$, tropisetron $5 \mathrm{mg}$ and granisetron $3 \mathrm{mg}$ given before induction of anesthesia. ${ }^{49}$

Dolasetron $12.5 \mathrm{mg}$ was also found to have similar efficacy to ondansetron $4 \mathrm{mg}$ with a similar side effect profile for the prevention of PONV. ${ }^{50,51}$ In an earlier study, dolasetron $50 \mathrm{mg}$ had similar efficacy to ondansetron $4 \mathrm{mg} .{ }^{52}$ Similarly, in a multicentre trial, it was demonstrated that $2 \mathrm{mg}$ tropisetron intravenously had similar efficacy and side effect profiles to those of ondansetron $4 \mathrm{mg} .{ }^{53}$ This was confirmed in another two trials comparing iv tropisetron $5 \mathrm{mg}$ with ondansetron $4 \mathrm{mg}$ and oral tropisetron $5 \mathrm{mg}$ with ondansetron $16 \mathrm{mg} .{ }^{54,55}$

Fujii and colleagues compared the antiemetic efficacy of granisetron 2.5 to $3 \mathrm{mg}$ and ramosetron 0.3 $\mathrm{mg}$ in three studies. There was no difference between the two agents in achieving a complete response (no PONV and no antiemetic rescue) during the first 24 hr postoperatively. Between 24 and $48 \mathrm{hr}$, however, ramosetron provided better prophylaxis. ${ }^{56-58}$

\section{Older generation antiemetics}

\section{A. DROPERIDOL}

Droperidol is a buterophenone that has been extensively used in anesthesia. In a dose of $1.25 \mathrm{mg}$, it was more cost-effective than ondansetron $4 \mathrm{mg}$ and was recommended as a first line agent for PONV prophylaxis (IA). ${ }^{59}$ The NNT to prevent early nausea was 5 . For both early and late vomiting, the best efficacy was with 1.5 to $2.5 \mathrm{mg}(\mathrm{NNT}=7) .{ }^{31}$ In children, the recommended dose is 50 to $75 \mu \mathrm{g} \cdot \mathrm{kg}^{-1}$ with a NNT of 4 (IIA). ${ }^{31}$ It has a long duration of action (as long as 24 $\mathrm{hr}$ following administration) probably due to its strong binding affinity to the emetic receptors; even though its half-life is relatively short (three hours) ${ }^{60}$ Droperidol is most effective when given at the end of surgery (IIA). ${ }^{31}$ It is also effective when given concomitantly with a patient-controlled analgesia system using morphine with a NNT (95\% CI) of 5.1 (3.1-15) and $3.1(2.3-4.8)$ for the prevention of nausea and vomiting respectively over the first $24 \mathrm{hr}$ postopera- 
tively (IIA). ${ }^{32}$ In this setting, the optimal antiemetic dose of droperidol was 15 to $50 \mu \mathrm{g} \cdot \mathrm{mg}^{-1}$ of morphine (IIIA). ${ }^{61}$ Sedation and drowsiness are important side effects of droperidol and are dose dependent. Low doses of droperidol $(0.625-1.25 \mathrm{mg})$ were not associated with any increased sedation compared to ondansetron $4 \mathrm{mg}$ (IA). ${ }^{62}$

In December 2001, the Food and Drug Administration (FDA) issued a new 'black box' warning on droperidol, which is the most serious warning for a FDA-approved drug. The FDA noted that its use has been associated with QTc segment prolongation and/or torsades de pointes, and in some cases resulted in fatal cardiac arrhythmias. A review of the cases on which the FDA issued its warning, revealed ten cases where droperidol $1.25 \mathrm{mg}$ or less was used. It is difficult to draw any definitive evidence of a cause and effect relationship due to the presence of several confounding factors. The incidence of cardiac adverse events following the administration of droperidol has been estimated at 74 in 11 million. Following the black box warning, there has been a tenfold decrease in the use of droperidol in the USA. ${ }^{63}$ In Canada, while droperidol is still available, there are limitations to its use issued by Health Canada. Following similar safety concerns raised by the UK Medicines Control Agency (MCA) regarding the chronic use of highdose oral droperidol in psychiatric patients, the manufacturer (Janssen-Cilag, Ltd.) decided to withdraw all formulations of droperidol. The decision to stop producing the parenteral formulation of droperidol was based solely on economic reasons, even though the MCA included a statement in the "Information for Patients" brochure that allowed the continued acute use of droperidol in anesthesia and as an antiemetic. ${ }^{64}$

\section{B. METOCLOPRAMIDE}

High-dose metoclopramide (1-2 $\left.\mathrm{mg} \cdot \mathrm{kg}^{-1}\right)$ has been used successfully in the management of chemotherapy-induced emesis. In order to reduce the side effects seen with these doses, notably sedation and dystonic reactions, lower doses $\left(0.1-0.2 \mathrm{mg} \cdot \mathrm{kg}^{-1}\right)$ have been employed in the management of PONV. However, the efficacy of metoclopramide in preventing PONV at these doses is uncertain, with approximately $50 \%$ of studies showing it to be no more effective than placebo. ${ }^{65}$ In a systematic review of randomized placebocontrolled studies involving metoclopramide, Henzi $e t$ al. reported that there was no significant anti-nausea effect. The NNT to prevent early $(0-6 \mathrm{hr})$ and late (within $48 \mathrm{hr}$ ) vomiting were 9.1 and 10 respectively. ${ }^{35}$ Indeed, most members of the recent consensus panel could not recommend metoclopramide as an antiemetic. ${ }^{7}$ A recent study, however, suggested that $20 \mathrm{mg}$ might be an efficacious dose (IIIB). ${ }^{66}$

\section{OTHER OLDER GENERATION ANTIEMETICS}

Anticholinergics block muscarinic cholinergic central nervous system emetic receptors in the cerebral cortex and pons. ${ }^{27}$ Scopolamine has the most potent antiemetic properties in this class of drugs with a NNT of 3.8 for the prevention of PONV. ${ }^{29}$ The transdermal preparation should be applied the evening prior or four hours before the end of surgery (IIB). ${ }^{29}$ Its limitations include a two- to four-hour onset of effect, as well as its medical contraindications and age related considerations. ${ }^{67}$ The $\mathrm{NNH}$ for the most commonly reported side effects was 5.6, 12.5, 50, and 100 for dry mouth, visual disturbances, dizziness, and agitation respectively. ${ }^{29}$

The antihistamines include the ethanolamines (dimenhydrinate, diphenhydramine) and the piperazines (cyclizine, hydroxyzine, meclizine). Many of these agents have only been tested in single agent studies. The recommended dose for dimenhydrinate is 1 to $2 \mathrm{mg} \cdot \mathrm{kg}^{-1}$ in adults and $0.5 \mathrm{mg} \cdot \mathrm{kg}^{-1}$ in children (IIA). ${ }^{30}$ The NNT $(95 \%$ CI) to stay completely free from nausea was 8 (3-20) during the first six hours postoperatively and 6 (3-33) for the period from zero to $48 \mathrm{hr}$. For vomiting, the NNT (95\% CI) was $7(4-50)$ and $5(3-8)$ for the early and the 48 -hr period respectively. ${ }^{30}$ The recommended dose for cyclizine is $50 \mathrm{mg}$ (IIIA). ${ }^{68}$ Their major disadvantages are sedation, dry mouth, blurred vision, urinary retention, and delayed recovery room discharge. ${ }^{69}$ Promethazine is an effective antiemetic with a long duration of action. In a dose of 12.5 to $25 \mathrm{mg}$ given towards the end of surgery, it has been shown to be effective for PONV management (IIIB). ${ }^{70}$ Its use, however, is limited by sedation and prolonged recovery from anesthesia. ${ }^{65} \mathrm{~A}$ recent study, however, did not show increased awakening time or duration of PACU stay when compared to ondansetron and placebo in patients undergoing middle ear surgery. ${ }^{70}$

Similarly, chlorpromazine demonstrated efficacy in the prevention and treatment of PONV (IIIB). ${ }^{71,72}$ Its many side effects, particularly sedation and hypotension, limit its use as an antiemetic.

The heterocyclic phenothiazines (prochlorperazine and perphenazine) have similar antiemetic efficacy, but perphenazine causes more sedation., ${ }^{71,73}$ The recommended dose for prochlorperazine is 5 to $10 \mathrm{mg} i m$ in adults (IIIA) ${ }^{74}$ In children, the recommended dose for perphenazine is $70 \mu \mathrm{g} \cdot \mathrm{kg}^{-1}$ (IA). ${ }^{75,76}$ These compounds have, however, a higher incidence of extrapyramidal side effects compared to the aliphatic phenothiazines. $^{77}$ 


\section{Non-conventional antiemetics}

\section{A STEROIDS}

Following the successful use of dexamethasone in the prevention and treatment of chemotherapy induced emesis, this agent has been evaluated and found to be effective for the management of PONV. ${ }^{78,79}$ The recommended dose is 5 to $10 \mathrm{mg}$ in adults (IIA) $)^{37,80,81}$ and $150 \mu \mathrm{g} \cdot \mathrm{kg}^{-1}$ in children (IIA). ${ }^{37}$ More recently, smaller doses $(2.5-5 \mathrm{mg})$ have been found to be effective (IIIA) ${ }^{80,82}$ In a meta-analysis, Henzi suggested that dexamethasone might be particularly effective against late PONV with a NNT of 4.3 for the prevention of late nausea and vomiting. ${ }^{37}$ Dexamethasone appears to be most effective when administered prior to induction of anesthesia rather than at the end in preventing early PONV (0-2 hr); (IIIA). ${ }^{82}$ There are no reports of dexamethasone related adverse effects in the doses used for the management of PONV (IIA). ${ }^{37}$

\section{B. PROPOFOL}

Total $i v$ anesthesia (TIVA) with propofol is associated with a lower incidence of PONV compared with inhalational agents (IIIA). ${ }^{83-85}$ In one study, this technique was equally efficacious to ondansetron $4 \mathrm{mg}$ in the prevention of PONV (IIIA). ${ }^{18}$ The antiemetic effect of propofol is most pronounced in the early postoperative period. It is not useful for PONV prophylaxis if given only as a bolus for induction of anesthesia (IIA). ${ }^{36}$ More recently, continuous subhypnotic propofol infusion and the use of patient-controlled antiemesis with propofol were also found to be effective in the treatment of PONV (IIIA). ${ }^{86,87}$ The effective plasma concentration of propofol for the $50 \%$ reduction in nausea scores has been found to be 343 $\mathrm{ng} \cdot \mathrm{mL}^{-1}$. This is much lower than the range required for sedation $\left(900-1,300 \mathrm{ng} \cdot \mathrm{mL}^{-1}\right)$ and anesthesia $\left(3,000-10,000 \mathrm{ng} \cdot \mathrm{mL}^{-1}\right){ }^{88}$

\section{Future therapies}

Animal studies demonstrated broader spectrum antiemetic activity of the neurokinin-l (NKl) receptor antagonists compared with the $5 \mathrm{HT}_{3}$ receptor antagonists. ${ }^{89}$ In humans, NKl receptor antagonists were effective for the prophylaxis and treatment of PONV (IIIA). ${ }^{90,91}$ In one study in females undergoing gynecologic surgery, the $\mathrm{NKl}$ receptor antagonist provided better prophylaxis against vomiting compared with ondansetron. The combination of both agents also significantly prolonged the time to administration of rescue antiemetics compared with either drug alone, and was associated with a very low incidence of emesis $(2 \%) .{ }^{91}$
5. Other interventions with potential antiemetic effects Benzodiazepines were found to be effective for the prophylaxis of PONV (IB)..$^{92-94}$ The successful use of midazolam in cases of persistent PONV and following failure of other antiemetics has also been described (IIIB).$^{95-97}$ Intramuscular ephedrine $\left(0.5 \mathrm{mg} \cdot \mathrm{kg}^{-1}\right)$ has been shown to be effective for PONV prophylaxis especially in the early postoperative period $(0-3 \mathrm{hr})$ (IIIB).$^{98-100}$ Alpha $_{2}$ adrenergic agonists also significantly reduced the incidence of PONV in both children and adults (IIIA). ${ }^{101,102}$ It has been suggested that the antiemetic effect of clonidine might be secondary to a reduction in the use of volatile agents and opioids, or a reduction in sympathetic tone. ${ }^{102}$ In two studies by one group, oxygen supplementation (80\%) intraoperatively or both intraoperatively and for two hours postoperatively was effective in achieving a significant reduction in the incidence of PONV compared to patients receiving $30 \%$ oxygen (IIIB). ${ }^{103,104}$ These findings were not confirmed in a more recent study in females undergoing ambulatory gynecologic surgery. In this study, $80 \%$ oxygen was given intraoperatively and for up to one hour postoperatively. ${ }^{105}$ Adequate hydration was also associated with a significant reduction in the incidence of PONV (IB). ${ }^{106}$ In a more recent study, a combination of colloid and crystalloid fluid resuscitation was associated with less PONV and less use of rescue antiemetics, compared with the administration of crystalloids alone in patients undergoing major abdominal procedures (IIIA). ${ }^{107}$

\section{Non-pharmacological techniques}

Several investigators have shown a useful effect of non-pharmacological methods in the management of PONV. A few studies, however, failed to demonstrate a beneficial effect. Lee and Done performed a systematic review of 24 randomized trials of acupuncture, electroacupuncture, transcutaneous electrical nerve stimulation, acupoint stimulation and acupressure. They found that there was a significant reduction in early PONV (0-6 hr) in adults treated with acupuncture compared with placebo and that antiemetics (metoclopramide, cyclizine, droperidol, prochlorperazine) $v s$ acupuncture techniques were comparable in preventing early and late $(0-48 \mathrm{hr})$ PONV in adults. These techniques were more effective for controlling nausea than vomiting. In children, however, no benefit was found (IIA). ${ }^{38}$ More recently, however, the effectiveness of acupuncture for the prophylaxis of PONV in children has been demonstrated (IIIA). ${ }^{108-111}$ In a recent randomized placebo controlled study in patients undergoing breast surgery, 
Gan and colleagues reported similar efficacy of electroacupuncture at the $\mathrm{P} 6$ point and prophylactic ondansetron. Of interest electroacupuncture patients reported less pain compared with the other groups (IIIA). ${ }^{112}$ The comparable efficacy of acupoint electrical stimulation to ondansetron for both the prophylaxis and treatment of PONV was also confirmed in two recent studies (IIIA). When used for prophylaxis, the combination of ondansetron and acupoint electrical stimulation was associated with lower incidence of PONV, less need for rescue antiemetics as well as improved quality of recovery and patient satisfaction, compared to ondansetron alone. ${ }^{113,114}$ Hypnosis has also been found effective when compared with placebo (IIIB). ${ }^{115}$ Although some earlier reports suggested that ginger root might have a beneficial effect for PONV prophylaxis, this has not been confirmed in a recent meta-analysis (IIA). ${ }^{116}$

\section{Combination antiemetic therapy and multimodal approach}

None of the available antiemetics is entirely effective for preventing PONV, especially in high-risk patients. Since at least four major receptor systems are involved in the etiology of PONV, a better prophylaxis might be achieved by using a combination of agents acting at different receptor sites. This approach, introduced first in chemotherapy induced nausea and vomiting, is gaining more popularity for PONV prophylaxis. More than 40 randomized controlled trials were published comparing combination vs single agent for PONV prophylaxis. Most of these studies demonstrated improved prophylaxis using a combination of two or more agents acting at different receptor sites. ${ }^{117,118}$ This has also been confirmed in systematic reviews (IIA). ${ }^{37,119}$

The most commonly studied combinations have included a $5-\mathrm{HT}_{3}$ receptor antagonist with either droperidol or dexamethasone. Both combination regimens appear to be equally efficacious (IIA). ${ }^{120,121}$

In addition to using a combination of antiemetics acting at different receptor sites, the multifactorial etiology of PONV might be better addressed by the adoption of a multimodal approach. This is especially important in patients at high risk for PONV.

Table VI summarizes different strategies for keeping the baseline risk of PONV low, together with the supporting level of evidence. For instance, there is an 11 fold increased risk for PONV in patients receiving general anesthesia compared to those receiving a regional anesthetic. ${ }^{15}$ TIVA with propofol has been shown to reduce the incidence of PONV, especially in the early postoperative period. ${ }^{36}$ Avoidance of nitrous oxide (which increases postoperative vomiting) and volatile agents (which cause PONV for up to two hours postoperatively), and minimizing intraoperative and postoperative opiates, also reduce the incidence of PONV. ${ }^{2,8-13}$ The use of large doses of neostigmine (> $2.5 \mathrm{mg}$ ) increases the risk of PONV. ${ }^{14}$ Other strategies that might reduce the incidence of PONV include the use of supplemental intraoperative oxygen $\left(\mathrm{FiO}_{2}=\right.$ $0.8),{ }^{103,104}$ adequate hydration especially using colloids, ${ }^{106,107}$ anxiolysis with benzodiazepines, ${ }^{122}$ and the use of $\alpha_{2}$-agonists. ${ }^{101,102}$

Scuderi et al. tested a multimodal approach to the management of PONV in females undergoing outpatient laparoscopy. Their multimodal critical care algorithm consisted of total $i v$ anesthesia with propofol and remifentanil, no nitrous oxide, no neuromuscular blockade, aggressive iv hydration $\left(25 \mathrm{~mL} \cdot \mathrm{kg}^{-1}\right)$, triple prophylactic antiemetics (ondansetron $1 \mathrm{mg}$, droperidol $0.625 \mathrm{mg}$ and dexamethasone $10 \mathrm{mg}$ ), and ketorolac $30 \mathrm{mg}$. Control groups included standard balanced outpatient anesthetic with or without $4 \mathrm{mg}$ ondansetron prophylaxis. Multimodal management resulted in a $98 \%$ complete response rate (no PONV and no antiemetic rescue) in PACU. No patient in this group vomited before discharge, compared with $7 \%$ of patients in the ondansetron group $(P=0.07)$ and $22 \%$ of patients in the placebo group $(P=0.0003) .{ }^{123}$ Subsequently, more studies confirmed the efficacy of a multimodal approach, especially in high-risk patients (IIIA). ${ }^{124,125}$

\section{Post-discharge nausea and vomiting}

Ambulatory surgery is continuing to grow. PONV is a major problem in this setting since it prolongs the time to discharge and reduces patient satisfaction. ${ }^{126}$ While the prophylaxis and management of PONV occurring in PACU has significantly improved, nausea and vomiting occurring following discharge from PACU remains under treated. Nausea and vomiting occurring in PACU may not accurately predict the incidence after discharge. Approximately 36\% of patients who experience post-discharge nausea and vomiting do not experience any nausea or vomiting prior to discharge. In an analysis of all studies evaluating patient-reported symptoms after outpatient surgery, the overall incidence of nausea and vomiting occurring following discharge from hospital has been estimated to be $17 \%$ (range $0-55 \%$ ) and $8 \%$ (range $0-16 \%$ ) respectively. ${ }^{127}$ This not only leads to a delay in resumption of daily activities, but also can be distressing to the patients in the absence of available treatment. ${ }^{128}$ Most of the available antiemetics have short half-lives and may not be effective after dis- 
TABLE VI Strategies to keep the baseline risk of postoperative nausea and vomiting low

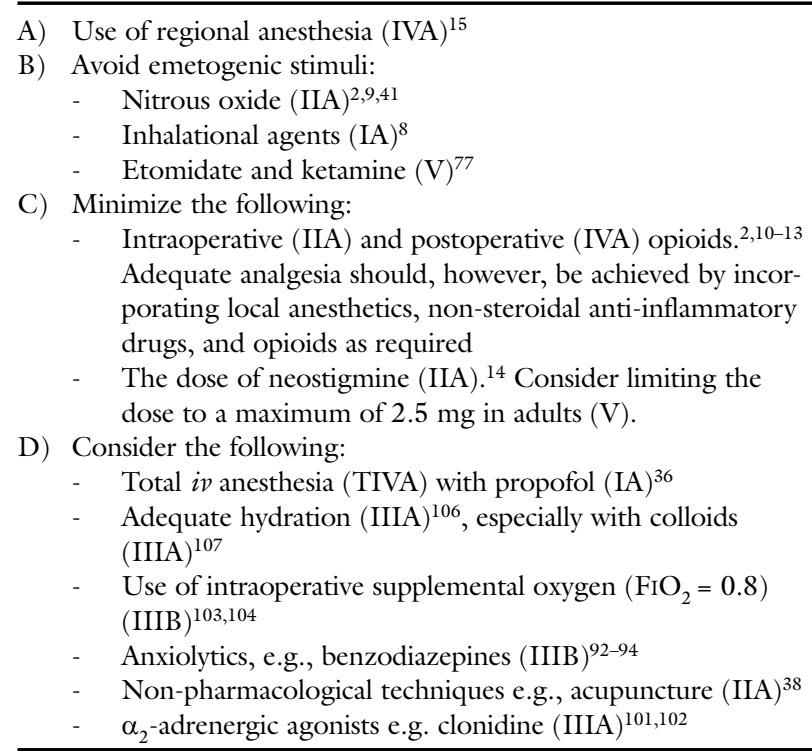

charge. Administration of prophylactic antiemetics following discharge may therefore be warranted in highrisk patients. Therapies that have shown to be effective in reducing the incidence and severity of post-discharge nausea and vomiting include ondansetron orally disintegrating tablet (IIIA), ${ }^{129}$ transcutaneous acupoint electrical stimulation on the P6 point (only reduced nausea) (IIIA), ${ }^{130}$ and the use of a transdermal scopolamine patch (IIIA). ${ }^{67}$

In a recent meta-analysis, the NNT to prevent postdischarge nausea following ambulatory surgery was $12.9,12.2$, and 5.2 following the prophylactic administration of ondansetron $4 \mathrm{mg}$, dexamethasone, and a combination of two antiemetics respectively. For postdischarge vomiting, the NNT was 13.8 for ondansetron $4 \mathrm{mg}$ and 5 for combination treatment. In this analysis, droperidol was not effective for the prophylaxis against post-discharge nausea and vomiting. These results suggest that ondansetron alone should not be used routinely in low-risk ambulatory patients and that high risk patients are best managed with a combination strategy (IIA). ${ }^{131}$

\section{Cost-effectiveness}

In this era of evidence-based medicine and cost-effective medical practice, it is important to examine the available evidence in order to select the most suitable intervention for a given patient population. The most cost-effective approach to the management of PONV will differ between an ambulatory centre and an inpatient hospital setting. In this context, nursing labour costs are more likely to be directly related to the duration of PACU stay in an office-based setting and, to a lesser extent, an ambulatory surgery unit, whereas prolonged PACU stay may not have a significant impact in nursing labour costs in an inpatient hospital setting, unless nursing staff can be reduced. Since lower doses of ondansetron $(1 \mathrm{mg})$ are effective for treatment of established PONV compared with the doses needed for prophylaxis, Tramer et al. concluded that prophylaxis with ondansetron in all patients is less cost-effective than treatment with the same drug. ${ }^{132}$ In patients at high-risk for PONV, however, Hill and colleagues reported that prophylactic antiemetic use was costeffective and was associated with greater patient satisfaction compared to no prophylaxis. They reported that the additional costs associated with PONV in placebo patients were up to 100 times more expensive compared with prophylaxis with a generic compound. Most of the costs were from nursing labour costs secondary to prolonged PACU stay as a result of persistent PONV. The cost of treating vomiting was three times more than the cost of treating nausea. ${ }^{59}$ Similar results were reported in another study where both droperidol and dolasetron were more cost-effective than no prophylaxis in high-risk patients. ${ }^{133}$ In two separate cost-effectiveness analyses, Tang et al. and Hill et al. reported that droperidol was more cost-effective than ondansetron for PONV prophylaxis. ${ }^{59,134}$ Watcha and Smith determined that prophylaxis was only cost-effective if the incidence of PONV exceeded 33\% with ondansetron and $13 \%$ with droperidol. ${ }^{135}$

Since the different $5-\mathrm{HT}_{3}$ receptor antagonists have comparable efficacy and safety profiles, it was determined that acquisition cost was the main factor that differentiated the $5-\mathrm{HT}_{3}$ compounds from one another. ${ }^{7}$

\section{Recommended strategy for PONV prophylaxis}

The risk of PONV should be estimated for each patient. No prophylaxis is recommended for patients at low risk for PONV except if they are at risk for medical consequences from vomiting e.g., patients with wired jaws. For patients at moderate to high risk for PONV, regional anesthesia should be considered. If this is not possible or contraindicated and a general anesthetic is used, a multimodal approach to the management of PONV should be adopted to keep the baseline risk of PONV low (Table VI). Combination antiemetic therapy is superior to monotherapy for PONV prophylaxis (IIA). ${ }^{37,117,119}$ The addition of TIVA to a combination of two antiemetics results in a further improved prophylaxis (IIIA). ${ }^{136}$ Figure illus- 


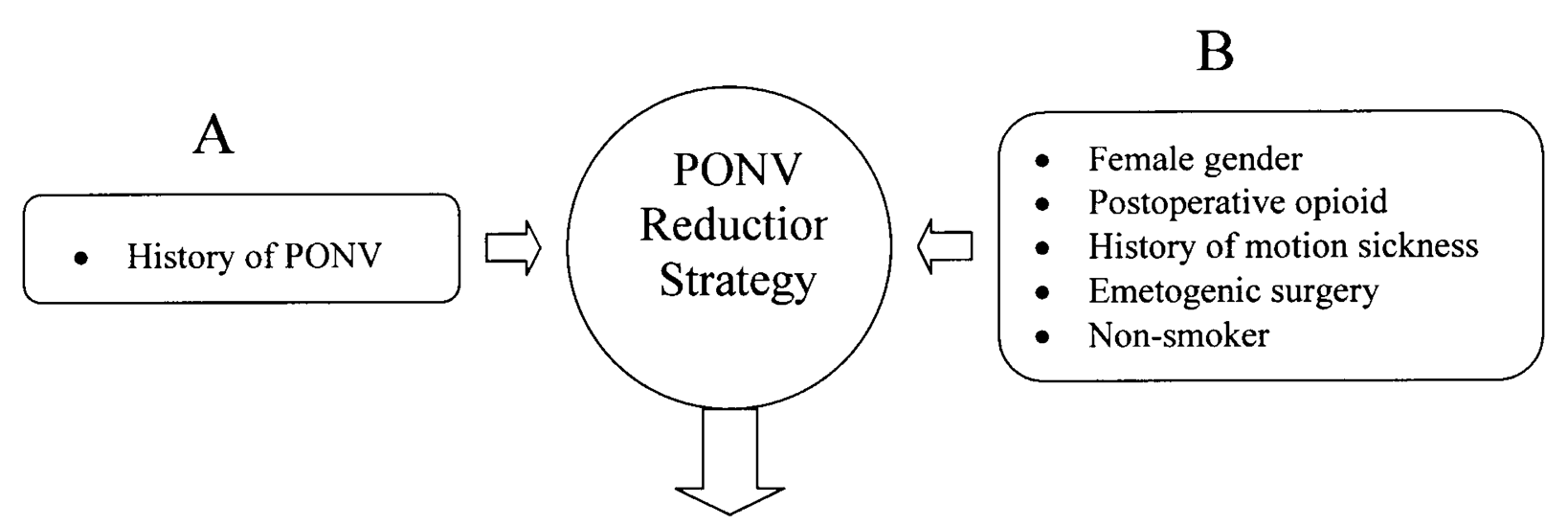

Consider

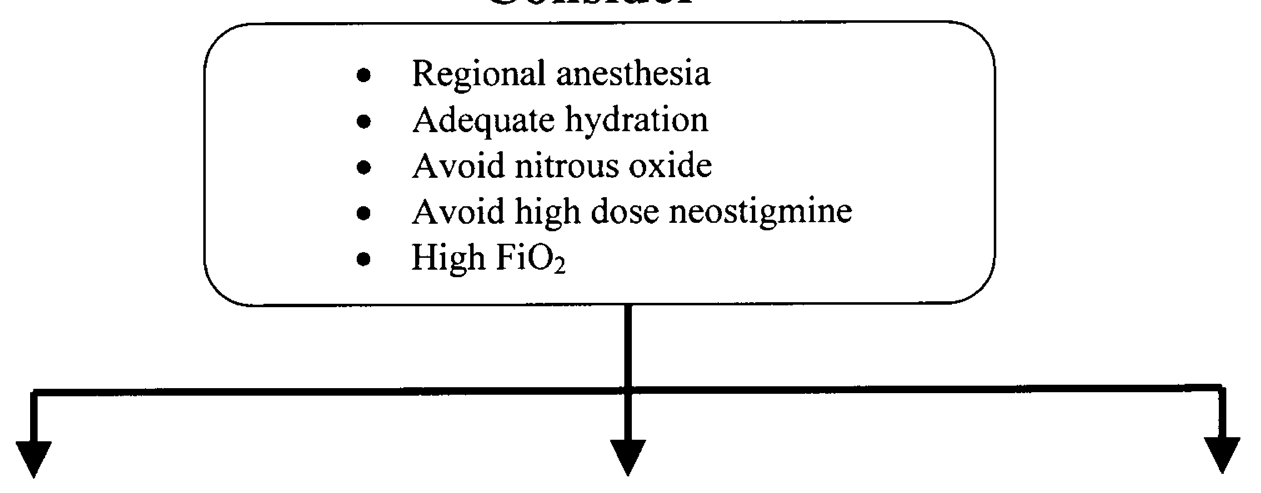

A on one occasion OR 2 factors from $\mathbf{B}$

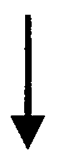

Single Agent

- $5-\mathrm{HT}_{3}$ antagonist

- Droperidol*

- Dexamethasone

- Scopolamine

- Promethazine

- Acupuncture
A on one occasion

PLUS $\geq 1$ factor from $B$

$\mathbf{O R} \geq 3$ factors from $\mathbf{B}$

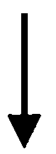

Combination of 2 Agents

- 5- $\mathrm{HT}_{3}$ antagonist +

Dexamethasone

- 5-HT3 antagonist +

Droperidol*

- 5- $\mathrm{HT}_{3}$ antagonist + Acupuncture
A on more than one occasion PLUS $\geq 1$ factor from $\mathbf{B}$

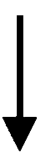

\section{Multimodal}

$\geq 2$ antiemetics

PLUS

TIVA with Propofol 
TABLE VIII PONV treatment for patients who failed prophylaxis or did not receive prophylaxis

\begin{tabular}{|c|c|c|}
\hline Initial therapy & Rescue treatment & Level of evidence \\
\hline No prophylaxis or dexamethasone & $\begin{array}{l}\text { - Low dose } 5-\mathrm{HT}_{3} \text { receptor } \\
\text { antagonist: ondansetron } 1 \mathrm{mg} \text {, } \\
\text { dolasetron } 12.5 \mathrm{mg} \text {, } \\
\text { tropisetron } 0.5 \mathrm{mg} \text {. } \\
\text { - Dexamethasone } 2-4 \mathrm{mg} \text {, } \\
\text { promethazine } 6.25 \mathrm{mg} \\
\text { droperidol } 0.625 \mathrm{mg} \text {. }\end{array}$ & - IIA 137 \\
\hline $\begin{array}{l}5-\mathrm{HT}_{3} \text { receptor antagonist } \\
\text { plus a second agent }\end{array}$ & $\begin{array}{l}\text {-Antiemetic from a } \\
\text { different class }\end{array}$ & $-\operatorname{IVB}^{139}$ \\
\hline $\begin{array}{l}\text { Triple therapy with } 5-\mathrm{HT}_{3} \\
\text { receptor antagonist plus two }\end{array}$ & - Do not repeat initial therapy & - $\mathrm{IA}^{138,144}$ \\
\hline \multirow[t]{2}{*}{$\begin{array}{l}\text { other agents when PONV } \\
\text { occurs }<6 \text { hr postoperatively }\end{array}$} & - Use antiemetic from a different class & - IVB $^{139}$ \\
\hline & $\begin{array}{l}\text { - Use propofol, } 20 \mathrm{mg} \\
\text { as needed in PACU (adults) }\end{array}$ & - IIIA ${ }^{87}$ \\
\hline \multirow{2}{*}{$\begin{array}{l}\text { Triple therapy with } 5-\mathrm{HT}_{3} \\
\text { receptor antagonist plus two } \\
\text { other agents when PONV } \\
\text { occurs }>6 \text { hr postoperatively }\end{array}$} & $\begin{array}{l}\text { - Repeat low-dose } 5-\mathrm{HT}_{3} \\
\text { receptor antagonist and droperidol, } \\
\text { but NOT dexamethasone or scopolamine. }\end{array}$ & $-\mathrm{V}$ \\
\hline & - Use an antiemetic from a different class. & $-\mathrm{IVB}^{139}$ \\
\hline
\end{tabular}

$\mathrm{PONV}=$ postoperative nausea and vomiting; PACU $=$ postanesthesia care unit.

trates a suggested algorithm for PONV prophylaxis.

\section{Recommendations for the treatment of established PONV}

There is a paucity of data on the use of antiemetics for the treatment of PONV in patients who failed prophylaxis or did not receive prophylaxis. This is due to the difficulty in performing such studies since a large number of patients would need to be recruited in order to obtain the required target of patients who eventually experience PONV.

The $5-\mathrm{HT}_{3}$ receptor antagonists were the most commonly tested drugs in rescue trials.

Similar to their use in PONV prophylaxis, the antivomiting efficacy of the $5-\mathrm{HT}_{3}$ receptor antagonists is more pronounced than their anti-nausea efficacy. There is no evidence of dose-responsiveness for these agents when used for rescue. Therefore, small doses of these agents have been recommended for treatment: ondansetron $1 \mathrm{mg}$, dolasetron $12.5 \mathrm{mg}$, granisetron 0.1 $\mathrm{mg}$ and tropisetron $0.5 \mathrm{mg}$ (IIA). ${ }^{137}$ The NNT for the different doses of the 5-HT3 receptor antagonists when used for treatment range from 2.9 to 11 (Table VII, available as Additional Material at www.cja-jca.org).

In patients who fail ondansetron prophylaxis, there is evidence to suggest that the use of ondansetron for rescue is no more effective than placebo (IA). ${ }^{138} \mathrm{~A}$ drug acting at a different receptor might be more effective in this case (IVB). ${ }^{139}$ There are some data from chemotherapy induced nausea and vomiting to suggest that granisetron might be efficacious for treating patients who fail ondansetron prophylaxis. ${ }^{140,141}$ Such evidence is lacking in the PONV literature. There is also a striking lack of evidence on the therapeutic efficacy of older generation antiemetics in the treatment of established PONV. Droperidol was not different from ondansetron when used for the treatment of established PONV (IIA). ${ }^{142}$ On the other hand, ondansetron $4 \mathrm{mg}$ was more effective than metoclopramide $10 \mathrm{mg}$ in the treatment of established PONV (IIIA). ${ }^{13,143}$

When evaluating PONV following surgery, the role of medication and mechanical factors should be considered first. Such contributing factors might include opiates, blood draining down the throat, or bowel obstruction. Then rescue therapy can be initiated. If PONV occurs within six hours postoperatively, patients should not receive a repeat dose of the prophylactic antiemetic; a drug from a different class should be used for rescue. Beyond six hours, PONV can be treated with any of the agents used for prophylaxis except dexamethasone and scopolamine, which are longer acting. The recommendations made by the consensus panel with the corresponding level of evidence are summarized in Table VIII. ${ }^{7}$

In summary, the identification of patients at increased risk for PONV allows targeting antiemetic prophylaxis to those who will benefit most from it. No prophylaxis is warranted for patients at low risk for PONV unless there is risk of medical sequelae from 
vomiting. The first step in reducing PONV risk is to reduce baseline risk factors. For patients at moderate to high risk, antiemetics should be used either as monotherapy or in combination for PONV prophylaxis. There is increasing evidence that a better prophylaxis might be achieved by using a combination of agents acting at different receptors. The adoption of a multimodal approach to the management of PONV should be considered in patients at high risk for PONV. In patients who develop PONV despite receiving prophylaxis, an antiemetic acting at a different receptor should be used for rescue within the first six hours following surgery. ${ }^{144}$ After six hours, PONV can be treated with any of the drugs used for prophylaxis except dexamethasone and scopolamine.

\section{References}

1 Cohen MM, Duncan PG, DeBoer DP, Tweed WA. The postoperative interview: assessing risk factors for nausea and vomiting. Anesth Analg 1994; 78: 7-16.

2 Apfel CC, Laara E, Koivuranta M, Greim CA, Roewer N. A simplified risk score for predicting postoperative nausea and vomiting: conclusions from cross-validations between two centers. Anesthesiology 1999; 91: 693-700.

3 Gold BS, Kitz DS, Lecky JH, Neuhaus JM. Unanticipated admission to the hospital following ambulatory surgery. JAMA 1989; 262: 3008-10.

4 Myles PS, Williams DL, Hendrata M, Anderson H, Weeks $A M$. Patient satisfaction after anaesthesia and surgery: results of a prospective survey of 10811 patients. Br J Anaesth 2000; 84: 6-10.

5 Macario A, Weinger M, Carney S, Kim A. Which clinical anesthesia outcomes are important to avoid? The perspective of patients. Anesth Analg 1999; 89: 652-8.

6 Gan T, Sloan F, Dear Gde L, El-Moalem HE, Lubarsky $D A$. How much are patients willing to pay to avoid postoperative nausea and vomiting? Anesth Analg 2001; 92: 393-400.

7 Gan TJ, Meyer T, Apfel CC, et al. Consensus guidelines for managing postoperative nausea and vomiting. Anesth Analg 2003; 97: 62-71.

8 Apfel CC, Kranke P, Katz MH, et al. Volatile anaesthetics may be the main cause of early but not delayed postoperative vomiting: a randomized controlled trial of factorial design. $\mathrm{Br} \mathrm{J}$ Anaesth 2002; 88: 659-68.

9 Tramer M, Moore A, McQuay H. Omitting nitrous oxide in general anaesthesia: meta-analysis of intraoperative awareness and postoperative emesis in randomized controlled trials. Br J Anaesth 1996; 76: 186-93.
10 Apfel CC, Kranke P, Eberhart LH, Roos A, Roewer N. Comparison of predictive models for postoperative nausea and vomiting. Br J Anaesth 2002; 88: 234-40.

11 Sukbani R, Vazquez J, Pappas AL, Frey K, Aasen M, Slogoff $S$. Recovery after propofol with and without intraoperative fentanyl in patients undergoing ambulatory gynecologic laparoscopy. Anesth Analg 1996; 83: 975-81.

12 Moiniche S, Romsing J, Dabl JB, Tramer MR. Nonsteroidal antiinflammatory drugs and the risk of operative site bleeding after tonsillectomy: a quantitative systematic review. Anesth Analg 2003; 96 : 68-77.

13 Polati E, Verlato G, Finco G, et al. Ondansetron versus metoclopramide in the treatment of postoperative nausea and vomiting. Anesth Analg 1997; 85: 395-9.

14 Tramer MR, Fuchs-Buder T. Omitting antagonism of neuromuscular block: effect on postoperative nausea and vomiting and risk of residual paralysis. A systematic review. Br J Anaesth 1999; 82: 379-86.

15 Sinclair DR, Chung F, Mezei G. Can postoperative nausea and vomiting be predicted? Anesthesiology 1999; 91: 109-18.

16 Koivuranta M, Laara E, Snare L, Alahubta S. A survey of postoperative nausea and vomiting. Anaesthesia 1997; 52: 443-9.

17 Fabling JM, Gan TJ, El-Moalem HE, Warner DS, Borel CO. A randomized, double-blinded comparison of ondansetron, droperidol, and placebo for prevention of postoperative nausea and vomiting after supratentorial craniotomy. Anesth Analg 2000; 91: $358-61$.

18 Gan TJ, Ginsberg B, Grant AP, Glass PS. Doubleblind, randomized comparison of ondansetron and intraoperative propofol to prevent postoperative nausea and vomiting. Anesthesiology 1996; 85: 1036-42.

19 Beattie WS, Lindblad T, Buckley DN, Forrest JB. Menstruation increases the risk of nausea and vomiting after laparoscopy. A prospective randomized study. Anesthesiology 1993; 78: 272-6.

20 Honkavaara P, Lehtinen AM, Hovorka J, Korttila K. Nausea and vomiting after gynaecological laparoscopy depends upon the phase of the menstrual cycle. Can J Anaesth 1991; 38: 876-9.

21 Gratz I, Allen E, Afshar M, Joslyn AF, Buxbaum J, Prilliman $B$. The effects of the menstrual cycle on the incidence of emesis and efficacy of ondansetron. Anesth Analg 1996; 83: 565-9.

22 Eberbart LH, Morin AM, Georgieff M. The menstruation cycle in the postoperative phase. Its effect of the incidence of nausea and vomiting (German). 
Anaesthesist 2000; 49: 532-5.

23 Kranke P, Apfel CC, Papenfuss T, et al. An increased body mass index is no risk factor for postoperative nausea and vomiting. A systematic review and results of original data. Acta Anaesthesiol Scand 2001; 45: 160-6.

24 Stadler M, Bardiau F, Seidel L, Albert A, Boogaerts $J G$. Difference in risk factors for postoperative nausea and vomiting. Anesthesiology 2003; 98: 46-52.

25 Rose JB, Watcha MF. Postoperative nausea and vomiting in paediatric patients. Br J Anaesth 1999; 83: 104-17.

26 Cohen MM, Cameron CB, Duncan PG. Pediatric anesthesia morbidity and mortality in the perioperative period. Anesth Analg 1990; 70: 160-7.

27 Lerman J. Surgical and patient factors involved in postoperative nausea and vomiting. Br J Anaesth 1992; 69: 24S-32S.

28 Palazzo M, Evans R. Logistic regression analysis of fixed patient factors for postoperative sickness: a model for risk assessment. Br J Anaesth 1993; 70: 135-40.

29 Kranke P, Morin AM, Roewer N, Wulf H, Eberhart $L H$. The efficacy and safety of transdermal scopolamine for the prevention of postoperative nausea and vomiting: a quantitative systematic review. Anesth Analg 2002; 95: 133-43.

30 Kranke P, Morin AM, Roewer N, Eberbart LH. Dimenhydrinate for prophylaxis of postoperative nausea and vomiting: a meta-analysis of randomized controlled trials. Acta Anaesthesiol Scand 2002; 46: 238-44.

31 Henzi I, Sonderegger J, Tramer MR. Efficacy, doseresponse, and adverse effects of droperidol for prevention of postoperative nausea and vomiting. Can J Anesth 2000; 47: 537-51.

32 Tramer MR, Walder B. Efficacy and adverse effects of prophylactic antiemetics during patient-controlled analgesia therapy: a quantitative systematic review. Anesth Analg 1999; 88: 1354-61.

33 Tramer MR, Reynolds DJ, Moore RA, McQuay HJ. Efficacy, dose-response, and safety of ondansetron in prevention of postoperative nausea and vomiting: a quantitative systematic review of randomized placebocontrolled trials. Anesthesiology 1997; 87: 1277-89.

34 Kranke P, Eberhart LH, Apfel CC, Broschert J, Geldner $G$, Roewer N. Tropisetron for prevention of postoperative nausea and vomiting: a quantitative systematic review (German). Anaesthesist 2002; 51: 805-14.

35 Henzi I, Walder B, Tramer MR. Metoclopramide in the prevention of postoperative nausea and vomiting: a quantitative systematic review of randomized, place- bo-controlled studies. Br J Anaesth 1999; 83: 761-71.

36 Tramer $M$, Moore A, McQuay $H$. Propofol anaesthesia and postoperative nausea and vomiting: quantitative systematic review of randomized controlled studies. Br J Anaesth 1997; 78: 247-55.

37 Henzi I, Walder B, Tramer MR. Dexamethasone for the prevention of postoperative nausea and vomiting: a quantitative systematic review. Anesth Analg 2000; 90: 186-94.

38 Lee A, Done ML. The use of nonpharmacologic techniques to prevent postoperative nausea and vomiting: a meta-analysis. Anesth Analg 1999; 88: 1362-9.

39 Sun R, Klein KW, White PF. The effect of timing of ondansetron administration in outpatients undergoing otolaryngologic surgery. Anesth Analg 1997; 84: 331-6.

40 Tang J, Wang B, White PF, Watcha MF, Qi J, Wender $R H$. The effect of timing of ondansetron administration on its efficacy, cost-effectiveness, and cost-benefit as a prophylactic antiemetic in the ambulatory setting. Anesth Analg 1998; 86: 274-82.

41 Tramer $M$, Moore A, McQuay $H$. Meta-analytic comparison of prophylactic antiemetic efficacy for postoperative nausea and vomiting: propofol anaesthesia vs omitting nitrous oxide vs total i.v. anaesthesia with propofol. Br J Anaesth 1997; 78: 256-9.

42 Graczyk SG, McKenzie R, Kallar S, et al. Intravenous dolasetron for the prevention of postoperative nausea and vomiting after outpatient laparoscopic gynecologic surgery. Anesth Analg 1997; 84: 325-30.

43 Chen X, Tang J, White PF, et al. The effect of timing of dolasetron administration on its efficacy as a prophylactic antiemetic in the ambulatory setting. Anesth Analg 2001; 93: 906-11.

44 Wilson AJ, Diemunsch P, Lindeque BG, et al. Singledose i.v. granisetron in the prevention of postoperative nausea and vomiting. Br J Anaesth 1996; 76 : 515-8.

45 Mikawa K, Takao $\Upsilon$, Nishina K, Shiga M, Maekawa $N$, Obara $H$. Optimal dose of granisetron for prophylaxis against postoperative emesis after gynecological surgery. Anesth Analg 1997; 85: 652-6.

46 D'Angelo R, Minkowitz H, Dalby P, et al. A pilot, randomized, double-blind, dose-ranging study of intravenous granisetron (Kytrilß) in the prevention of postoperative nausea and vomiting (PONV) in subjects undergoing abdominal hysterectomy. New York Society of Anesthesiologists Postgraduate Assembly 2002.

47 Taylor AM, Rosen M, Diemunsch PA, Thorin D, Houweling PL. A double-blind, parallel-group, placebo-controlled, dose-ranging, multicenter study of 
intravenous granisetron in the treatment of postoperative nausea and vomiting in patients undergoing surgery with general anesthesia. J Clin Anesth 1997; 9: 658-63.

48 Fujii $\Upsilon$, Saitoh $\Upsilon$, Tanaka H, Toyooka $H$. Ramosetron for preventing postoperative nausea and vomiting in women undergoing gynecological surgery. Anesth Analg 2000; 90: 472-5.

49 Naguib M, el Bakry AK, Khoshim MH, et al. Prophylactic antiemetic therapy with ondansetron, tropisetron, granisetron and metoclopramide in patients undergoing laparoscopic cholecystectomy: a randomized, double-blind comparison with placebo. Can J Anaesth 1996; 43: 226-31.

50 Zarate E, Watcha MF, White PF, Klein K, Rego MS, Stewart DG. A comparison of the costs and efficacy of ondansetron versus dolasetron for antiemetic prophylaxis. Anesth Analg 2000; 90: 1352-8.

51 Walker JB. Efficacy of single-dose intravenous dolasetron versus ondansetron in the prevention of postoperative nausea and vomiting. Clin Ther 2001; 23: 932-8.

52 Korttila K, Clergue F, Leeser J, et al. Intravenous dolasetron and ondansetron in prevention of postoperative nausea and vomiting: a multicenter, doubleblind, placebo-controlled study. Acta Anaesthesiol Scand 1997; 41: 914-22.

53 Scholz J, Hennes HJ, Steinfath M, et al. Tropisetron or ondansetron compared with placebo for prevention of postoperative nausea and vomiting. Eur J Anaesthesiol 1998; 15: 676-85.

54 Tsui SL, Ng KF, Wong LC, Tang GW, Pun TC, Yang $J C$. Prevention of postoperative nausea and vomiting in gynaecological laparotomies: a comparison of tropisetron and ondansetron. Anaesth Intensive Care 1999; 27: 471-6.

55 Jokela R, Koivuranta M, Kangas-Saarela T, Purbonen $S$, Alabubta $S$. Oral ondansetron, tropisetron or metoclopramide to prevent postoperative nausea and vomiting: a comparison in high-risk patients undergoing thyroid or parathyroid surgery. Acta Anaesthesiol Scand 2002; 46: 519-24.

56 Fujii $\Upsilon$, Saitoh $\Upsilon$, Tanaka H, Toyooka H. Comparison of ramosetron and granisetron for preventing postoperative nausea and vomiting after gynecologic surgery. Anesth Analg 1999; 89: 476-9.

57 Fujii $\Upsilon$, Saitoh $\Upsilon$, Tanaka H, Toyooka H. Ramosetron vs granisetron for the prevention of postoperative nausea and vomiting after laparoscopic cholecystectomy. Can J Anesth 1999; 46: 991-3.

58 Fujii $\Upsilon$, Tanaka $H$. Comparison of granisetron and ramosetron for the prevention of nausea and vomiting after thyroidectomy. Clin Ther 2002; 24:
766-72.

59 Hill RP, Lubarsky DA, Phillips-Bute B, et al. Costeffectiveness of prophylactic antiemetic therapy with ondansetron, droperidol, or placebo. Anesthesiology 2000; 92: 958-67.

60 Fischler $M$, Bonnet $F$, Trang $H$, et al. The pharmacokinetics of droperidol in anesthetized patients. Anesthesiology 1986; 64: 486-9.

61 Culebras X, Corpataux JB, Gaggero G, Tramer MR. The antiemetic efficacy of droperidol added to morphine patient-controlled analgesia: a randomized, controlled, multicenter dose-finding study. Anesth Analg 2003; 97: 816-21.

62 Fortney JT, Gan TJ, Graczyk S, et al. A comparison of the efficacy, safety, and patient satisfaction of ondansetron versus droperidol as antiemetics for elective outpatient surgical procedures. S3A-409 and S3A-410 Study Groups. Anesth Analg 1998; 86: 731-8.

63 Habib AS, Gan TJ. Food and drug administration black box warning on the perioperative use of droperidol: a review of the cases. Anesth Analg 2003; 96: 1377-9.

64 Gan TJ, White PF, Scuderi PE, Watcha MF, Kovac A. FDA "black box" warning regarding use of droperidol for postoperative nausea and vomiting: is it justified? (Letter) Anesthesiology 2002; 97: 287.

65 Rowbotham DJ. Current management of postoperative nausea and vomiting. Br J Anaesth 1992; 69: 46S-59S.

66 Quaynor $H$, Raeder JC. Incidence and severity of postoperative nausea and vomiting are similar after metoclopramide $20 \mathrm{mg}$ and ondansetron $8 \mathrm{mg}$ given by the end of laparoscopic cholecystectomies. Acta Anaesthesiol Scand 2002; 46: 109-13.

67 Bailey PL, Streisand JB, Pace NL, et al. Transdermal scopolamine reduces nausea and vomiting after outpatient laparoscopy. Anesthesiology 1990; 72 : 977-80.

68 Abmed AB, Hobbs GJ, Curran JP. Randomized, placebo-controlled trial of combination antiemetic prophylaxis for day-case gynaecological laparoscopic surgery. Br J Anaesth 2000; 85: 678-82.

69 Dundee JW, Assaf RA, Loan WB, Morrison JD. A comparison of the efficacy of cyclizine and perphenazine in reducing the emetic effects of morphine and pethidine. Br J Clin Pharmacol 1975; 2: 81-5.

70 Khalil S, Philbrook L, Rabb M, et al.

Ondansetron/promethazine combination or promethazine alone reduces nausea and vomiting after middle ear surgery. J Clin Anesth 1999; 11: 596-600.

71 Howat DD. Anti-emetic drugs in anaesthesia. A double blind trial of two phenothiazine derivatives. 
Anaesthesia 1960; 15: 289-97.

72 Dryberg V, Johansen SH. Pre-anaesthetic medication with chlorpromazine. A comparison with morphine. Acta Anaesthesiol Scand 1958; 2: 133-47.

73 Dundee JW, Moore J, Love WJ, Nicholl RM, Clarke $R S$. Studies of drugs given before anaesthesia. VI: the phenothiazine derivatives. Br J Anaesth 1965; 37: 332-52.

74 Chen JJ, Frame DG, White TJ. Efficacy of ondansetron and prochlorperazine for the prevention of postoperative nausea and vomiting after total hip replacement or total knee replacement procedures. A randomized, double-blind, comparative trial.[erratum: Arch Intern Med 1999; 159: 615]. Arch Intern Med 1998; 158: 2124-8.

75 Splinter $W$, Roberts DJ. Prophylaxis for vomiting by children after tonsillectomy: dexamethasone versus perphenazine. Anesth Analg 1997; 85: 534-7.

76 Splinter WM, Rhine EJ. Prophylaxis for vomiting by children after tonsillectomy: ondansetron compared with perphenazine. Br J Anaesth 1998; 80: 155-8.

77 Kovac AL. Prevention and treatment of postoperative nausea and vomiting. Drugs 2000; 59: 213-43.

78 Fujii $\Upsilon$, Tanaka $H$, Toyooka $H$. The effects of dexamethasone on antiemetics in female patients undergoing gynecologic surgery. Anesth Analg 1997; 85: 913-7.

79 Liu K, Hsu CC, Chia $\Upsilon$. Effect of dexamethasone on postoperative emesis and pain. Br J Anaesth 1998; 80: 85-6.

80 Liu K, Hsu CC, Chia $\Upsilon$ Y. The effect of dose of dexamethasone for antiemesis after major gynecological surgery. Anesth Analg 1999; 89: 1316-8.

81 Wang JJ, Ho ST, Lee SC, Liu YC, Ho CM. The use of dexamethasone for preventing postoperative nausea and vomiting in females undergoing thyroidectomy: a dose-ranging study. Anesth Analg 2000; 91: 1404-7

82 Wang JJ, Ho ST, Tzeng JI, Tang CS. The effect of timing of dexamethasone administration on its efficacy as a prophylactic antiemetic for postoperative nausea and vomiting. Anesth Analg 2000; 91: 136-9.

83 Price ML, Walmsley A, Swaine C, Ponte J. Comparison of a total intravenous anaesthetic technique using a propofol infusion, with an inhalational technique using enflurane for day case surgery. Anaesthesia 1988; 43: 84-7.

84 Doze VA, Shafer A, White PF. Propofol-nitrous oxide versus thiopental-isoflurane-nitrous oxide for general anesthesia. Anesthesiology 1988; 69: 63-71.

85 Lebenbom-Mansour MH, Pandit SK, Kothary SP, Randel GI, Levy L. Desflurane versus propofol anesthesia: a comparative analysis in outpatients. Anesth Analg 1993; 76: 936-41.
86 Kim SI, Han TH, Kil HY, Lee JS, Kim SC. Prevention of postoperative nausea and vomiting by continuous infusion of subhypnotic propofol in female patients receiving intravenous patient-controlled analgesia. Br J Anaesth 2000; 85: 898-900.

87 Gan TJ, El-Molem H, Ray J, Glass PS. Patient-controlled antiemesis: a randomized, double-blind comparison of two doses of propofol versus placebo. Anesthesiology 1999; 90: 1564-70.

88 Gan TJ, Glass PS, Howell ST, Grant AP, Ginsberg B. Determination of plasma concentrations of propofol associated with $50 \%$ reduction in postoperative nausea. Anesthesiology 1997; 87: 779-84.

89 Gardner CJ, Armour DR, Beattie DT, et al. GR205171: a novel antagonist with high affinity for the tachykinin $\mathrm{NK}_{1}$ receptor, and potent broad-spectrum anti-emetic activity. Regul Pept 1996; 65: 45-53.

90 Diemunsch P, Schoeffler P, Bryssine B, et al. Antiemetic activity of the $\mathrm{NK}_{1}$ receptor antagonist GR205171 in the treatment of established postoperative nausea and vomiting after major gynaecological surgery. Br J Anaesth 1999; 82: 274-6.

91 Gesztesi Z, Scuderi PE, White PF, et al. Substance P (Neurokinin-1) antagonist prevents postoperative vomiting after abdominal hysterectomy procedures. Anesthesiology 2000; 93: 931-7.

92 Splinter W, Noel LP, Roberts D, Rhine E, Bonn G, Clarke $W$. Antiemetic prophylaxis for strabismus surgery. Can J Ophthalmol 1994; 29: 224-6.

93 Splinter WM, MacNeill HB, Menard EA, Rbine EJ, Roberts DJ, Gould MH. Midazolam reduces vomiting after tonsillectomy in children. Can J Anaesth 1995; 42: 201-3.

94 Khalil SN, Berry JM, Howard G, et al. The antiemetic effect of lorazepam after outpatient strabismus surgery in children. Anesthesiology 1992; 77: 915-9.

95 Prasad V, Till CB, Smith A. Midazolam - an antiemetic? (Letter) Anaesthesia 2002; 57: 415.

96 Di Florio $T$. The use of midazolam for persistent postoperative nausea and vomiting. Anaesth Intensive Care 1992; 20: 383-6.

97 Di Florio T, Goucke CR. The effect of midazolam on persistent postoperative nausea and vomiting. Anaesth Intensive Care 1999; 27: 38-40.

98 Rothenberg DM, Parnass SM, Litwack K, McCarthy RJ, Newman LM. Efficacy of ephedrine in the prevention of postoperative nausea and vomiting. Anesth Analg 1991; 72: 58-61.

99 Naguib K, Osman HA, Al-Khayat HC, Zikri AM. Prevention of post-operative nausea and vomiting following laparoscopic surgery. Ephedrine vs propofol. Middle East J Anesthesiol 1998; 14: 219-30. 
100 Hagemann E, Halvorsen A, Holgersen O, Tveit T, Raeder JC. Intramuscular ephedrine reduces emesis during the first three hours after abdominal hysterectomy. Acta Anaesthesiol Scand 2000; 44: 107-11.

101 Mikawa K, Nishina K, Maekawa N, Asano M, Obara $H$. Oral clonidine premedication reduces vomiting in children after strabismus surgery. Can J Anaesth 1995; 42: 977-81.

102 Oddby-Mubrbeck E, Eksborg S, Bergendahl HT, Mubrbeck O, Lonnqvist PA. Effects of clonidine on postoperative nausea and vomiting in breast cancer surgery. Anesthesiology 2002; 96: 1109-14.

103 Goll V, Akca O, Greif R, et al. Ondansetron is no more effective than supplemental intraoperative oxygen for prevention of postoperative nausea and vomiting. Anesth Analg 2001; 92: 112-7.

104 Greif R, Laciny S, Rapf B, Hickle RS, Sessler DI. Supplemental oxygen reduces the incidence of postoperative nausea and vomiting. Anesthesiology 1999; 91: 1246-52.

105 Purbonen S, Turunen M, Ruoboabo UM, Niskanen M, Hynynen $M$. Supplemental oxygen does not reduce the incidence of postoperative nausea and vomiting after ambulatory gynecologic laparoscopy. Anesth Analg 2003; 96: 91-6.

106 Yogendran S, Asokumar B, Cheng DC, Chung F. A prospective randomized double-blinded study of the effect of intravenous fluid therapy on adverse outcomes on outpatient surgery. Anesth Analg 1995; 80: 682-6.

107 Moretti EW, Robertson KM, El-Moalem H, Gan TJ. Intraoperative colloid administration reduces postoperative nausea and vomiting and improves postoperative outcomes compared with crystalloid administration. Anesth Analg 2003; 96: 611-7.

108 Boebler MM, Mitterschiffthaler GM, Schlager A. Korean hand acupressure reduces postoperative nausea and vomiting after gynecological laparoscopic surgery. Anesth Analg 2002; 94: 872-5.

109 Schlager A, Offer T, Baldissera I. Laser stimulation of acupuncture point P6 reduces postoperative vomiting in children undergoing strabismus surgery. $\mathrm{Br} \mathrm{J}$ Anaesth 1998; 81: 529-32.

110 Rusy LM, Hoffman GM, Weisman SJ. Electroacupuncture prophylaxis of postoperative nausea and vomiting following pediatric tonsillectomy with or without adenoidectomy. Anesthesiology 2002; 96: 300-5.

111 Somri M, Vaida SJ, Sabo E, Yassain G, Gankin I, Gaitini LA. Acupuncture versus ondansetron in the prevention of postoperative vomiting. A study of children undergoing dental surgery. Anaesthesia 2001; 56: 927-32.
112 Gan TJ, Parrillo S, Fortney J, Georgiade G. Comparison of electroacupuncture and ondansetron for the prevention of postoperative nausea and vomiting. Anesthesiology 2001; 95: A22 (abstract).

113 Coloma M, White PF, Ogunnaike BO, et al. Comparison of acustimulation and ondansetron for the treatment of established postoperative nausea and vomiting. Anesthesiology 2002; 97: 1387-92.

114 White PF, Issioui T, Hu J, et al. Comparative efficacy of acustimulation (ReliefBand $®$ ) versus ondansetron (Zofran ${ }^{\circledR)}$ in combination with droperidol for preventing nausea and vomiting. Anesthesiology 2002; 97: 1075-81.

115 Enqvist B, Bjorklund C, Engman M, Jakobsson J. Preoperative hypnosis reduces postoperative vomiting after surgery of the breasts. A prospective, randomized and blinded study. Acta Anaesthesiol Scand 1997; 41: 1028-32.

116 Ernst E, Pittler MH. Efficacy of ginger for nausea and vomiting: a systematic review of randomized clinical trials. Br J Anaesth 2000; 84: 367-71.

117 Habib AS, Gan TJ. Combination therapy for postoperative nausea and vomiting - a more effective prophylaxis? Ambulatory Surgery 2001; 9: 59-71.

118 Habib AS, Gan TJ. Combination antiemetic. What is the evidence? Int Anesthesiol Clin Fall 2003; 41: 119-44.

119 Habib AS, El-Moalem HE, Gan TJ. Is the combination of $5-\mathrm{HT}_{3}$ receptor antagonists with droperidol or dexamethasone more effective than each agent alone for PONV prophylaxis? Anesthesiology 2001; 95: A20 (abstract).

120 Sanchez-Ledesma MJ, Lopez-Olaondo L, Pueyo FJ, Carrascosa F, Ortega A. A comparison of three antiemetic combinations for the prevention of postoperative nausea and vomiting. Anesth Analg 2002; 95: 1590-5.

121 Habib AS, El-Moalem HE, Gan TJ. The efficacy of the $5-\mathrm{HT}_{3}$ receptor antagonists combined with droperidol for PONV prophylaxis is similar to their combination with dexamethasone. A meta-analysis of randomized controlled trials. Can J Anesth 2004; 51: 311-19.

122 Habib AS. Midazolam - an anti-emetic? (Letter) Anaesthesia 2002; 57: 725.

123 Scuderi PE, James RL, Harris L, Mims GR 3rd. Multimodal antiemetic management prevents early postoperative vomiting after outpatient laparoscopy. Anesth Analg 2000; 91: 1408-14.

124 Hammas B, Thorn SE, Wattwil M. Superior prolonged antiemetic prophylaxis with a four-drug multimodal regimen - comparison with propofol or placebo. Acta Anaesthesiol Scand 2002; 46: 232-7. 
125 Eberhart LH, Mauch M, Morin AM, Wulf H, Geldner $G$. Impact of a multimodal anti-emetic prophylaxis on patient satisfaction in high-risk patients for postoperative nausea and vomiting. Anaesthesia 2002; 57 : 1022-7.

126 Tang J, Chen L, White PF, et al. Recovery profile, costs, and patient satisfaction with propofol and sevoflurane for fast-track office-based anesthesia. Anesthesiology 1999; 91: 253-61.

127 Wu CL, Berenholtz SM, Pronovost PJ, Fleisher LA. Systematic review and analysis of postdischarge symptoms after outpatient surgery. Anesthesiology 2002; 96: 994-1003.

128 Carroll NV, Miederhoff P, Cox FM, Hirsch JD. Postoperative nausea and vomiting after discharge from outpatient surgery centers. Anesth Analg 1995; 80: 903-9.

129 Gan TJ, Franiak R, Reeves J. Ondansetron orally disintegrating tablet versus placebo for the prevention of postdischarge nausea and vomiting after ambulatory surgery. Anesth Analg 2002; 94: 1199-200.

130 Zarate E, Mingus M, White PF, et al. The use of transcutaneous acupoint electrical stimulation for preventing nausea and vomiting after laparoscopic surgery. Anesth Analg 2001; 92: 629-35.

131 Gupta A, Wu CL, Elkassabany N, Krug CE, Parker $S D$, Fleisher LA. Does the routine prophylactic use of antiemetics affect the incidence of postdischarge nausea and vomiting following ambulatory surgery? A systematic review of randomized controlled trials. Anesthesiology 2003; 99: 488-95.

132 Tramer MR, Phillips C, Reynolds DJ, McQuay HJ, Moore RA. Cost-effectiveness of ondansetron for postoperative nausea and vomiting. Anaesthesia 1999 54: 226-34.

133 Frighetto L, Loewen PS, Dolman J, Marra CA. Costeffectiveness of prophylactic dolasetron or droperidol vs rescue therapy in the prevention of PONV in ambulatory gynecologic surgery. Can J Anesth 1999; 46: 536-43.

134 Tang J, Watcha MF, White PF. A comparison of costs and efficacy of ondansetron and droperidol as prophylactic antiemetic therapy for elective outpatient gynecologic procedures. Anesth Analg 1996; 83: 304-13.

135 Watcha MF, Smith I. Cost-effectiveness analysis of antiemetic therapy for ambulatory surgery. J Clin Anesth 1994; 6: 370-7.

136 Habib AS, White WD, Eubanks S, Papas TN,Gan TJ. A randomized comparison of a multimodal management strategy versus combination antiemetics for the prevention of postoperative nausea and vomiting. Anesth Analg 2004 (in press).
137 Kazemi-Kjellberg F, Henzi I, Tramer MR. Treatment of established postoperative nausea and vomiting: a quantitative systematic review. BMC Anesthesiol 2001; 1: 2.

138 Kovac AL, O'Connor TA, Pearman MH, et al. Efficacy of repeat intravenous dosing of ondansetron in controlling postoperative nausea and vomiting: a randomized, double-blind, placebo-controlled multicenter trial. J Clin Anesth 1999; 11: 453-9.

139 Hill RP, Soppitt AJ, Gan TJ. The effectiveness of rescue antiemetics in patients who received a prophylactic antiemetic. Anesth Analg 2000; 90: S8 (abstract).

140 Carmichael J, Keizer HJ, Cupissol D, Milliez J, Scheidel P, Schindler AE. Use of granisetron in patients refractory to previous treatment with antiemetics. Anticancer Drugs 1998; 9: 381-5.

141 de Wit R, de Boer AC, vd Linden GH, Stoter G, Sparreboom A, Verweiy J. Effective cross-over to granisetron after failure to ondansetron, a randomized double blind study in patients failing ondansetron plus dexamethasone during the first 24 hours following highly emetogenic chemotherapy. $\mathrm{Br}$ J Cancer 2001; 85: 1099-101.

142 Tramer MR, Moore RA, Reynolds DJ, McQuay HJ. A quantitative systematic review of ondansetron in treatment of established postoperative nausea and vomiting. BMJ 1997; 314: 1088-92.

143 Diemunsch P, Conseiller C, Clyti N, Mamet JP. Ondansetron compared with metoclopramide in the treatment of established postoperative nausea and vomiting. The French Ondansetron Study Group. Br J Anaesth 1997; 79: 322-6.

144 Scuderi PE, James RL, Harris L, Mims GR 3rd. Antiemetic prophylaxis does not improve outcomes after outpatient surgery when compared to symptomatic treatment. Anesthesiology 1999; 90: 360-71. 